\title{
1900 年パリ万国博における日本館の形態について THE MOTIVATION AND THE PURPOSE OF THE JAPANESE PAVILION'S FORM IN THE PARIS INTERNATIONAL EXPOSITION, 1900
}

\author{
三島雅博* \\ Masahiro MISHIMA
}

\begin{abstract}
The Japanese Government erected its pavilion, modeled after the main hall of Horyüji Temple, at the Paris International Exposition in 1900. The pavilion is important as one of the first buildings not simply modeled after a famous historical structure, but one that also combined different periodical details from the model. This paper reports the facts below.

The model's purpose was to represent the length of Japanese history. The pavilion's design was inspired by the exhibition inside which was the collection of Japanese art from each historical period. The important part of the design was done by Tadamasa Hayashi.
\end{abstract}

Keywords : exposition, Tadamasa Hayashi, Japanese-style, pavilion, Höryüji 万国博, 林 忠正, 伝統的日本建築, 日本館, 法隆寺

\section{I.はじめに}

万国博日本館は，藤岡・深谷両氏の論考 (1でも明らか にされているように，近代和風建築の形態的発達や，伝 統的日本建築（以下「日本建築」とする）に対する理念 を考察するうえで貴重な示唆を与えてくれる。この点か ら，筆者も明治 26 年のシカゴ万国博に於ける鳳凰殿の 歴史的意義について既に報告した2)。

本稿はこれに続き，1900 年パリ万国博の日本館の形 態について考察しょうとするものである。万国博日本館 については，これまで種々の評価がなされているが，そ の多くが通史的な研究に止まっており, 個々の建物の歴 史的意義について検討を要すると考えられる。

筆者は, 前回の鳳凰殿の検討に於いて, 日本館の建築 形態の決定に際し，その出展内容と建設経緯及び設計 者・建設関係者の理念が重要な役割を果たしていたこと を明らかにした。本稿は，前稿の視点を踏まえながら今 回の日本館の検討を行う。

しかし, 当時から粗雑な建築と評されたものであった ためが ${ }^{3)}$ ここの建物について論及した論考は少ない。そ の中でも先に挙げた藤岡・深谷両氏の研究は比較的深く 論及されてはいるが，やはり個別の検討はなされておら ず，本稿はそれを補完しようとするものである。

この日本館は「日本建築」の形態を持ち, 範を法隆寺 金堂に求めたものであったが，それとは時代的に異なる

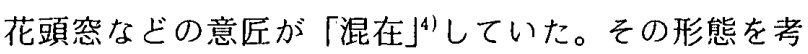

察するに際し，設計者が重要であるが，その名は当時の 報告書 ${ }^{5}$ (以下『報告書」とする)には記されていない。 このことについて, カロリーヌ・マチュー氏は, フラン ス側の資料を基にしたものと思われるが, 日本館を「Ch. レニエと J. プティグランの作」とされている6 。しかし, 今回の研究で設計に関する新たな史料を発見したので, 設計者を改めて問い直す必要があると考えられる。

従って, 本稿では 1900 年パリ万国博の日本館建設の 経緯を探り設計者を問い直したうえで，法隆寺金堂に範 を求めたことや混在が行われたことの理由や目的につい て考察し，この日本館の歴史的意義を明らかにしょうと するものである。

なお，本研究には主な資料として，『報告書』，新聞》 及び『官報】,さらに当時の雑誌などを使用した。また, 林忠正の事蹟については，主に定塚武敏氏の著作 ${ }^{8)}$ を参 考とした。

\section{II. 日本館建設確定までの経緯}

\section{II-1 1900 年パリ万国博参同と体制}

『報告書』では，日本政府が 1900 年パリ万国博開催の 予定を知ったのは，明治 28 年当時パリに駐在していた 全権公使曾穤荒助が意見書を添えて，このことを外務大 臣に報告したことによるとしている。しかし，万国博開 催のことは明治 25 年の「官報」の「外報」欄に報じら れていたから9，畺㪌の報告が政府にとっての初聞では 
なかった。翌 29 年 1 月, フランス政府より正式の参同 招請を受け，農商務省はその内容について検討を行った。 その結果, 同年 2 月 3 日農商務大臣は大体の参同方針を 決定, 同月 5 日の閣議でこれは可決され，フランス政府 に招請を受諾することを回答した。

このことにより農商務省は，前回のシカゴ万国博で実 績のあった宮中顧問官男爵九鬼隆一に参同への組織編成 その他の準備を委嘱し，また省内で取調委員を任命し， 官制や経費予算などの取り調べを行わせた。この調査に 基づき同年 5 月 9 日勅令第百八十九号を以て「臨時博覧 会事務局官制」が発布された。

この時の事務局で前回のシカゴ万国博の時と異なる点 は, 総裁副総裁に次ぐ地位として事務官長が定められた ことである。総裁には，その時々の農商務大臣があたり， 実質的責任者である副総裁, 事務官長には, 九鬼と金子 堅太郎がそれぞれ任命された。九鬼は，日本美術に誇り を持ち, その発展を積極的に押し進めていた人物で, シ カゴ万国博の時には鳳凰殿の建設目的や形態形成に重要 な役割を果たしていた。その時と同様に, 今回の出品方 針も，彼の思想を反映して国粋を重視したものとなって (る ${ }^{10)}$ 。金子も積極的に事務官長として活動していたよ うであるが,翌 30 年 4 月にその職を辞している。この後, 適任者がいなかった為か, 事務官長はしばしば任命され ず，この間九鬼が負担しなければならない職責は大きく なっていたと考えられる。

しかし，その九鬼も翌 31 年 2 月 28 日には辞職してし

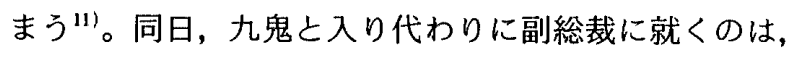
この万国博への参同を決定した時のパリ駐在全権公使で あり, 当時の司法大臣兽電荒助であった。また同年 3 月 3 日に，曽䨍の引き立てにより，パリで日本の古美術品 を扱う美術商であった林忠正が永く空席のままであった 事務官長に就く ${ }^{121}$ 。民間人である林を登用するために， わざわざ官制を改正してまでの抜擢であった。林の日本 美術特に浮世絵についての知識は相当のものであった が，明治美術会に属するなど日本の美術界においては洋 画の推進に積極的であり，この点で九鬼とは対称的な立 場を採っていた。事実，林の就任により，出品方針は大 きく変化し，特に美術出品の方針は「国粋主義から国際 主義」へと大きく転回した13)。

さらに，曾穤も同年 6 月 30 日に司法大臣を免官とな るが, 官制により自動的に副総裁も解職となり ${ }^{14)}$, この 後副総裁は空席のままで万国博終了後の事務局解散を迎 える。このことから，事務官長である林が，実質的責任 者として活動していたことがわかる。

\section{II-2 日本古美術品の出品}

この時の日本館の展示は, 奈良時代から江戸時代まで の日本の古美術品を陳列し, 日本美術の変遷を示そうと したものであったが，そのために皇室をはじめ各地の社
寺や名家富豪から名品が未曾有の規模で集められた。

『報告書」や当時の新聞では, これらの古美術品を出 品することになったのは，有栖川親王が明治 30 年にイ ギリスで行われた英国国王即位 60 周年祭に参列し，そ の帰途にパリへ立ち寄った際に, フランスのアノトー外 務大臣から 1900 年パリ万国博への日本の古美術品の出 品を要請されたことによるとしている。親王はパリ滞在 中に，アノトーの招待で晚餐会に出席したことを当時の 新聞は報じている。これは同年 7 月初めのことで，この 時に要請はなされたと思われる。

しかし, 古美術品の出品はアノトーの要請によって初 めて考え出されたのではなく,それ以前に布石があった。 この万博では, 古美術品の展示と共にフランス語による “Histoire de l'art du Japon” (『帝国美術略史 ${ }^{15)}$ ) が刊 行されたが，この準備のために岡會覚三・福地復一の三 人が事務局から「日本帝国美術歴史編纂事務」に任命さ れるのは, アノトーの要請に先立つ明治 30 年 4 月 7 日 のことである。さらに同年 5 月中の新聞は, 美術史の編 篹だけでなく古美術品も出品することを報じている。

来る冊三年開会の仏国の万国博覧会には古代美術の展覧会を も併せ開く筈にて我国より古代美術品を蒐集して出品し（以

下略）【「日本美術史の編筫」「読売新聞】(M 30.5.23)】

この後, 美術史の編築は九鬼が総長であり岡倉や福地 が一員であった帝国博物館に依頼され，同年 9 月にはこ れを同館が正式に承諾する。このように,アノトーの要 請以前に『帝国美術略史」や古美術品の出品が考えられ ていたが, 九鬼が前回のシカゴ万国博同様, この万博を 日本美術の優秀さを海外に広める機会として捉えたこと は考えうる。また, フランス側からの要請は, 九鬼の構 想を大規模に展開させたと言ってよい。

その要請を受け, 古美術品の出品が正式に決定した日 時は，『報告書』などの史料には記されていないが，林 忠正の談話から，凡その時期を知ることができる。

丁度其頃は大隈伯が博覧会の総裁で居られたときと思はれる 其でそのときは大抵此方の政府に於ても事情が能く分って居 るし又日本政府として承諾すべき事柄であったからして承諾 することに決して此方より公式的に御請求に応じて日本より 古美術品を出陳致すべしと答へた

【「巴里博覽会と日本古代美術一林忠正氏の談一」

『東京日日新聞」(M 33.1.1)】

大隈重信が総裁を辞したのは，明治 30 年 11 月 6 日で あるからここれ前に出品が決定していたことになる。

ところで, 翌 31 年に入ると民間団体から日本館建設 の建議書が事務局総裁に提出される。

来る三十三年仏国巴里に開く万国博筧会へ本邦より出品する ものは別に日本館を建設せず同国の建物中に陳列することに 決定し居りし処此程全国実業団体総代として前田正名氏より 同会総裁たる農商務大臣へ是非日本館を建設せらるべしとの 理由を詳記したる建議畫を提出したる由なるが（略） 


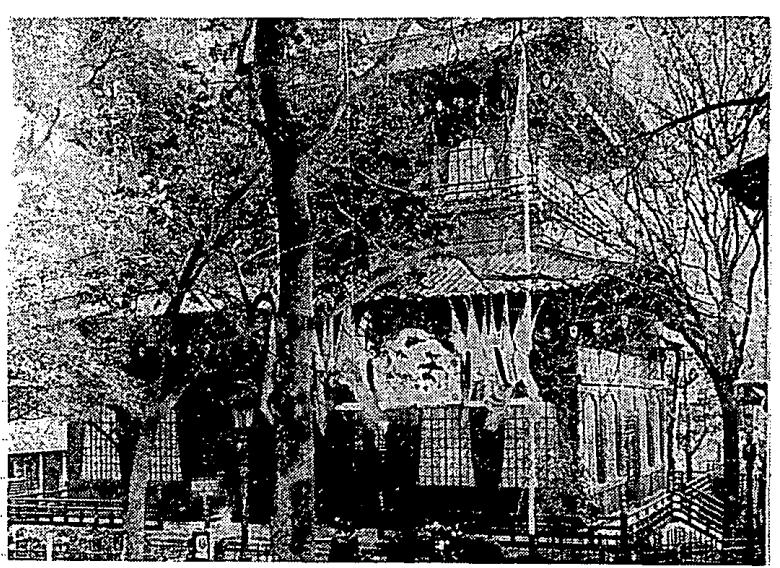

图一1 日本館【「九九百年巴里万国博覧会出品聯合協会報告」(巴 里万国博覧会出品聯合協会残務取扱所, 明治 36 年)】

【「日本館建築の建議」「読売新聞】(M 31.2.19)】

ここでいう日本館は, 古美術品出品のためではなく, 一般出品物の陳列のための建物を指すとも考えられる が，いずれにせよ，日本館と言われる施設の建設がこの 時点では決定していなかったことがわかる。

また，林は同年 3 月 3 日に事務官長に任命されるが, この時点では, 古美術品の陳列方法や陳列場所などは確 定していなかったとしている。

是（古美術品の出品のこと：筆者註）を実行する方法は如何 であるか又其陳列すべき場所はドコであるかと云ふことの如 きは未だ確定しなかった（略）私が事務局に這入った頃は未 だ其事柄があると云ふことのみを受け次ぐに止まった

【前揭「巴里博筧会と日本古代美術」】

林は当初, 古美術品をフランス側が建設した陳列場や 美術館に展示できると考えたが, そのための場所は準備 されておらず不可能であった。それにより，林は古美術 品の展示施設として日本館建設を計画する。林が就任し た時点で日本館建設が未確定であったことは，建設費用 が参同予算の中に盛り込まれていなかったことからもわ かるが，それも同年 5 月から 6 月にかけて開かれた国会 第十二議会に追加継続費として提出され; 容れられた。 これにより，日本館の建設が正式に決定した。

II-3 敷地の獲得と用途

日本館の敷地は，当初からその建設が計画されていな かったため, 日本庭園用に請求していたものを転用した ものであった。しかし，『報告書』では，当初から日本 館の敷地を請求したように述べられており,このため, 請求内容に関する記述が暧昧で, その経過は分かりづら い。しかし，それを検討すると古美術品の展示という目 的を含め, 日本館建設の可能性は, 林の事務官長就任以 前からあったことがわかる。

事務局は，少なくよも明治 30 年 6 月. 7 日までに日本 庭園用として特別出品部の面積 $2000 \mathrm{~m}^{2}$ を請求してお $り^{16)}$ ，さらに，7月 16 日までには請求面積を $6000 \mathrm{~m}^{2} に$
増加していだ7)。その結果，9月20日付けでフランス 側総務部長ドローネーから, 日本庭園のためトロカデロ 地区で $2100 \mathrm{~m}^{2}$ を分割したことを通知される。さらに事 務局は, 翌 31 年 1 月 24 日付けで, 敷地の㹡張が可能で あるかを問い合わせたが，2 月 2 日付けで不可能である と回答される。

この敷地は平坦でないうえに，伐採や移植が許されな い樹木も多く，工事上不便が予想されるものであった。 さらに，トロカデロ地区は「殖民部」であったから，日 本が先進国として扱われていないことを示しかねないも のとなった。『報告書』では，これらの理由から，この 通知以前にケイ・ドルセー地区に代地を与えるか，もし くは面積を $6000 \mathrm{~m}^{2}$ にするよう請求したとしている。 従って, 請求面積を增加したのが明治 30 年 7 月 16 日以 前であるから，これ以前にフランス側からトロカデロの 敷地を打診されていたことが推測される。この時に重要 であるのは, ケイ・ドルセーを代替地として請求したこ とである。ここは「列国街」と呼ばれ，先進各国のパヴィ リオンが建ち並ぶ地区であった。よって,この請求は日 本館建設を前提としていたはずである。さらに，9月20 日付けでドローネーは, 敷地の位置や面積以外にも, そ こに建てる日本館は日本風の建築であって, 特定の時代 又は特定の地区を表現する必要があることを通知してお り，事務局がフランス側に日本館建設を打診していたで あろうことを窥わせる。以上のことから，この時点で日 本館建設が考慮されていたことが予想される。

しかし，ここで問題となるのは日本館の建設目的で, 明治 30 年 9 月 20 日付けのフランス側からの通知にある 日本館の呼称は, 『報告書』の記述では「該庭園内二建 築シ日本古美術品 陳列スヘキ特別館」となっており， この時点で日本館建設の目的が古美術品の展示に決定し ていたかのように思われる。ところが，事務局は翌 31 年 1 月 24 日付けで, トロカデロの日本館に古美術品の 陳列が可能であるかを問い合わせており，2月 2 日付け

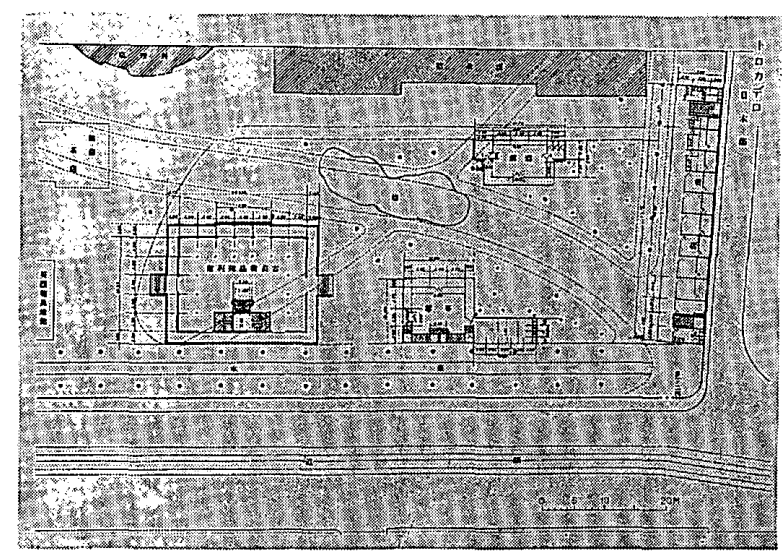

図一2 トロカデロ日本部 日本館 1 階平面図および配置図 【「仠九O年巴里万国博覧会臨時博筧会事秝局報告】(農 商務省、明治 35 年)】 
で可能と回答されている。これより，30 年 9 月 20 日付 けの通知は, 古美術品の陳列という目的に限定した日本 館に対してのものではなく，単にトロカデロに建てる日 本館に対してのものであったと思われる。また， 31 年 1 月 24 日付けの問い合わせから, この時点で, 古美術 品の展示を目的とした日本館建設が検討されていたこと がわかる。

このように，日本館の建設は林の事務官長就任以前か ら検討されていたのであり，林の立案によって突如生み 出されたものではなかったのである。

なお，敷地についての交渉は，日本館建設が正式に決 定した後も続けられた。明治 31 年 7 月に日本を出発し た林は，パり到着後，敷地の拡大を求めて数回に亘り交

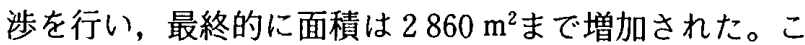
うして敷地が確定したのは翌 32 年 4 月のことであった。

\section{III. 日本館の設計者について}

冒頭でも述べたように，カロリーヌ・マチュー氏は日 本館をレニエとプティグランの作としている。また，当 時パリ滞在中であった日本の新聞記者も，日本館をフラ ンス人の設計であると報じている。

日本美術館の建築は木製にして，仏国技師仏国大工の手に成 りたるものなり。[「日本美術館の建築(巴里万国博覧会場内)」 【建築雑誌」(M 33.7)】

ここでいう「仏国技師」とは，レニエとプティグラン を指しているのであろう。しかし，マチュー氏は，彼ら が「日本建築」の形態を持つ日本館をどのように設計し たかについては，明らかにされてはいない。これに対し て，事務官長林忠正が日本館の設計について注目すべき 発言をしており，これについてはここまで論及された ことがないので，検討する必要がある。

III-1 林忠正の発言について

明治 32 年 4 月に，ようやく日本館の敷地が確定した が，これから設計図を作製して，フランス側事務局の承 認を得た後に日本に送り，国内で材料の切組などをして いては，開会に遅れる恐れがあるなど様々な問題があっ た。その結果，材料をフランスで求め，全ての工事をパ リで行うことにした。

明治三十一年七月林事務官長巴里二出張シ，仏国事務局卜交 涉ノ末地区ノ分割习確定シタル八明治三十二年四月ノ候二在 リ。之ヨリ建築設計図习作製シ, 之习仏国事務局二提出シテ 其ノ承認习経, 而シテ後之 $尹$ 本邦二送テ材料习切組マシメ, 更二之ヨ仏国二輸送スルトキ八, 其ノ間非常二時日ヨ要シ, 期二後ル、ノ楚アルノミナラス，其/費用多額二上リ且木材 八熱帯地方习経テ運般ノ途中差玨モ生スルノ慮アル 邦ヨリ材料习取ルコトハ之ヨ断念シ，一切仏国二於テ之ヨ経 営スルコト、ナシタリ。(略)

斯クテ其ノ設計八販壳店, 茶店及七酒輔ノ設計卜共二平面図 正面図切図等各六通ᄏ作少日夜調查, 上明治三十二年五月十
一日キ以テ之ヨ仏国事務局二提出シ，其ノ承認フ経，続テ林 事務官長八安達事務官, 斉藤事務官心得, 麻技師「レギェー」 「プチグラン」及ヒ「ギー」立会ノ上其ノ建築工事习入札二 附シ, 落札者ヨシテ直二工事二着手セシメタリ。

【「報告書】上巻第二編第六章第一節】

その後，5月11日に日本館だけでなく，日本品の販 売店, 喫茶店, 酒舗の設計図をフランス側事務局に提出 し，6月 6 日にトロカデロの敷地の引渡を受ける。こう して，パリでの仕事に一段落を付けた林は 6 月 16 日に パリを出発して 7 月 24 日に日本に帰国する。帰国した 当日，林は新聞記者から取材を受け，以下のような注目 すべき発言をしている。

参同列国の事務官は陳列館の利用及美術歴史工芸館等の建築 に就いては夫々設計をなし一々仏国博覧会事務局の許可を得 て設㣁せざるべからざる規定なり（略）

予は八ケ月の久しき自らコンパスを取りて或は美術上より或 は工芸上，或は建築学上より図案を作り大小四十二通りの設 計絵図及目論見を成功し事務局に呈出したるに（略）

【「林事務官長の談話」「東京日日新聞」(M 32.7.25)】

この発言の文字面からだけでも，林が八か月もかけて コンパスを必要とするだけの図面を作成していたことが わかるが，それが美術，工芸，建築の面から優れたもの となるよう努力している以上，その行為は単なる製図で はなく設計であったとしなければならない。また，文章 の前後関係から，その図面は「美術歴史工芸館」である 日本館のものを含むものと思われる。

さらに，林は明治 32 年 12 月 17 日に受けた新聞取材 では, 日本館について, 古美術品の出品経緯や建設の理 由について語った後に,自ら設計したことを述べている。

私は仏蘭西に出張中其れ（※）を列べる館と云ふものを設計 して建てることにした

（※ー日本から出品する古美術品のこと：筆者註）

【前揭「巴里博覧会と日本古代美術」】

これに引き続いて，林は日本館の形態だけでなく，そ の理由についてまでも説明している。

これら二つの発言から林が日本館を設計したのは確実 と考えられるが，マチュー氏は林の設計への関与を指摘 されておらず，跀龉を生ずることになる。

III -2 設計者の問題について

『報告書』の先の記述からは，日本館の設計図は，明 治 32 年 4 月の敷地確定後にパリで作成されたことにな る。ところが，図面を完成してフランス側事務局に提出 したのが同年 5 月 11 日のことであるから，あまりの短 期間ゆえに設計の開始時期は敷地確定よりも以前と考え ねばならない。しかし，少なくともフランス側の承認を 受けた正式の図面の作成者は当時パリにいた人物に限ら れ，日本館の設計との関係が注目される。先の引用文に 出てきた侓技師レギェー，プチグラン，ギーの三名は， 『報告書』ではいずれも「建築技師」となっており，前 
2 者は，マチュー氏が日本館の設計者とするレニエとプ ティグランのことと思われる。このことから，フランス 側に提出した図面の作成者としてレニ土とプティグラン がいたことは間違いないであろう。

ところで,林は自ら日本館を設計したと述べているが, 彼は本来，美術商であるから，建築物を設計する能力が あったかは疑問である。

これについて，『報告書」には，日本館と同時に図面 が提出された喫茶店の設計が林によって行われたことが 述べられている。

其ノ建築（唤茶店のこと：筆者註）二付テハ各種ノ図面 テ仏国事務局建築部ノ承認习受クヘキ規定（略）アルモ種々 ノ事情二掾り茶業組合中央会議所ヨリ設計引提出スルノ期甚 夕後レ，拱手シテ之ク待ツトキハ遂二仏国事務局ノ承認习得

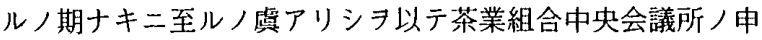
出习待タス, 当時巴里滞在ノ事務官長自ラ之ク設計シ日本館 設計卜共二三十二年五月十一日フ以テ之キ仏国事務局二提 出七り。【報告書】上巻第二編第七章第二節】

『報告書』は，美濃部俊吉が編箱主任となり，斉藤甲 子郎が補佐したものであるが，斉藤は喫茶店の設計時に 林とともにパリに派遺されていた人物であるからここの 記述は信頼性が高い。

ただ，建築家でない林が喫茶店の設計すべてを行うこ とができたとは考えられない。これについては当時の新 聞が状況を明らかにしてくれる。

巴里大博覽会場内に開設すべき唤茶店は本邦に於て凡ての材 料を切り組みをなし尚ほ内部の装飾品までも一切本邦品を以 てする計画なる處同地に滞在中の林事務官長は同地に於て一 切の建筑方を相応の技師に一任する方得策なるべく其経費の 如きも五万フラン (我二万円) にて充分なり尤も内部の装飾 は特に本邦より携帯するを可とすとの意見なるを以て（略） 【喫茶店の建築に就いて」「東京日日新聞」(M 32.4.23)】 この記事から，林はパリの「技師」に喫茶店の設計を 任すつもりであったことがわかる。よって先の『報告書』 の記述と考え合わせば，喫茶店の基本的な設計を林が自 ら行い，構造設計などを含む実際の設計を先のフランス 人技師に任せたことが推論できる。

これより，同様の設計体制が，日本館の場合も敷かれ ていたと考えられる。

以上のことから, 日本館の平面や外観などの形態形成 に、レニエとプティグランが関与したことを否定するこ とは出来ないまでも ${ }^{18)}$ ，林が「設計者」と呼べるような 主導的な役割を果たしていたことは間違いない。この時， 建築家としては素人である林が実施設計に携わることが なかったため，彼の名が正式な図面や書類に載ることが 無く、記録に残らなかったと推測される。日本館はフラ ンス人の設計であるとしていた先の『建築雑誌』の記事 も，記者が実施設計のことを捉えて報じたとしてよいで あろう。

また，設計がフランス側の承認を受ける前に日本に送
られ，官制上の責任者である事務局総裁の認可を受ける ことがなかったことについては，事務官長がパリ出張中 の場合，特例が許されていた。

総裁八事務官長仏国二出張中一定ノ事項二付テ八総裁ノ認許 ヨ経ス, 事務官長二於テ専断施行スベキヨ令達セラレタリ 【報告書】上巻第二編第一章第一節 $($ 一)】

この時に事務官長が総裁から委任され「専断施行」し てよい事項の一つに「会場内二於ケル家屋竝庭園築造及 修理ノ件」があった。これにより，林は総裁の許可無く とも，パリで日本館の設計を行うことができた。

さらに, 設計の開始時期を探ると, 日本館を自ら設計 し建設する意思が林に早くからあったことがわかる。林 は 8 か月間設計に従事したことを証言しており，設計図 のフランス側事務局への提出が明治 32 年 5 月 11 日であ るから, 逆算すれば前年の 9 月頃が設計の開始時期とな る。この時の出張では，林はパリに 30 年 8 月 7 日に到 着しているから，到着後まもなく設計を開始していたこ とになる。すなわち，林は敷地の確定が遅れなくとも， 日本館の設計を他の人物に委ねる気はなく，自らの手で やり遂げる自信があったのであろう。それ故に，敷地の 確定を明治 32 年 4 月まで遅らせることができたと言え よう。

\section{IV. 日本館の形態について}

IN-1 『報告書』の記述について

『報告書』では, 日本館のモデルについて, 高さの問 題から選定に苦心したとしている。日本の「古宮殿」は 平屋建が多いため，それをモデルにしたのでは世界各国 のパヴィリオンに閉じ込められたようになり，社寺の場 合でも同様であるとしている。このことからは，日本館 のモデルにまず求められたのは，世界各国のパヴィリオ ンに対抗しうる高さであったように思われる。

ところが，モデルに選ばれたのは，格別高い建物とし て知られているわけではない法隆寺金堂で，20メ一ト ル以上の高さにして, 日本の歴史的古さと壮大さとを同 時に表現しようとしたとしている。

因テ種々考究ノ末先ツ本体习法隆寺金堂二取ルコトニ決シ,

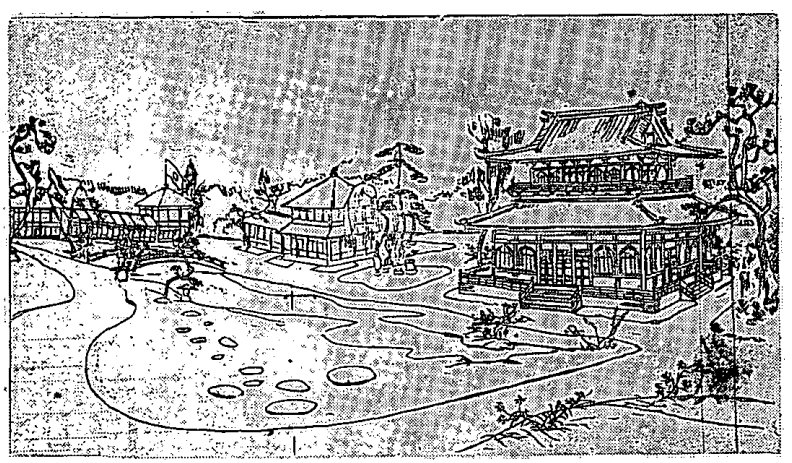

图一3 日本館【東京日日新聞】(M 32.7.25)】 
其ノ高尹二十「メートル」以上トナシ，本邦ノ古風习表顥ス ルト同時二壮大ノ観 ヨ求ムルコトヨ期シタリ。

【【報告畫】上巻第二篇第六章第一節】

法隆寺金堂は現存する日本最古の建築の一つであるか ら，従って，モデル選定にあたっては，高さよりも歴史 的古さを重視したことがわかる191。

法隆寺金堂をモデルとしたことは，身舎と庇の平面構 成, 立面が二層構成であり, 二層より初層の方が大きく, 二層の屋根が入母屋であること，二層目の高欄の存在な どに表れている。しかし，日本館の平面は五間 $\times$ 七間で あり，規模の面でそのモデルと異なるが，本稿で問題と するのはその形態であって，法隆寺金堂と時代が異なる 花頭窓などの意匠を用いたことである。『報告書』では， このことについて，以下のように説明している。

全然堂塔ヨ模センニ八, 其ノ四壁悉ク之ヨ白木造リトスル 要シ簡卒二過クルノミナラス, 光線 取ルニ便ナラサルラ以 テ先ツ四方二所謂釣鐘空 (※) ヨ設ケ, 其ノ壁面八秀衡ノ光

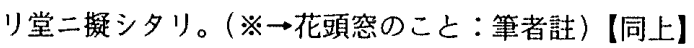

モデルをそのまま模したのでは，デザイン的に簡素過 ぎるだけでなく，採光上も問題があるため，花頭空を用 い,壁面を「秀衡ノ光り堂」に擬したというのであった ${ }^{20)}$ 。 これからは, 法隆寺金堂をモデルとしたために, 花頭空 などを用いねばならなかったように思える。

さらに, 花頭空を室町時代以降のものとしており, 法 隆寺金堂と時代的に異なることも認識していた。それに も係わらず，花頭窓を用いたのは，日本館の目的が一時 代を表現することではないという理由からとしている。

本館八強テ一時代ノ建築习表示スルノ目的二出テタルモノニ アラサル ツ以テ便宜上之 (花頭空のこと：筆者註）７取リタ ルナリ。【同上】

この理由は，全ての法隆寺金堂亡異なる時代の意匠の 使用についてもあてはまるであろう。

それでは何故，歴史的古さを表現するために法隆寺金 堂をモデルに選んだにも係わらず，それをあえて表現す る必要が無かったのか。また，何故日本館は一時代を表 現する必要が無かったのか。これらの疑問は, 混在の根 本的な目的に関わる問題である。

このことは, 日本館の形態形成に重要な役割を果たし た林の発言から確かめねばならない。

IV-2 林忠正の発言からの考察

林が設計を終えて一時帰国していた間に行った発言 は,『報告書』に記されていない重要な事実を教えてく れる。

極く善い時代の古い式でさうして金堂の如きものを建てるこ とにした何故仏堂の形にしたかと云ふに（略）日本の建築と して誇るべきものは堂塔伽藍の建築式である其れから又日本 の古い美術と云ふもの〉発達したるは仏法に據って成立って 居るから古美術品の源は皆古仏像古仏画及其れに附属したも
のである旁々以て仏堂の式に法り建てたら中にある品物も亦 是を入れてある鞘に相応じて調和が善いであらうと思ふて仏 堂の形ちにした【前揭「巴里博覧会と日本古代美術」】

林が日本館のモデル選定にあたり，まず設定したのは， 『報告書』に記されているような高さではなく，仏寺建 築であった。その理由は第一に，「日本建築」として誇 るべきものが仏寺建築であることで，これは，以前の日 本館建設の際にも無意識にも存在していたのであろう が，林はそれを抽出した。第二は，日本の古美術品が仏 教により発達したものであるから，容れ物もそれに忘じ て仏寺建築とすればよいと考えていたことで，この発想 は日本館の形態を考察するうえで重要となる。

これに続いて，林は以下のように述べる。

併ながら例へば法隆寺の金堂にしても日本に於ては小さくも 見へぬけれども巴里の街の家を見た眼から見ると云ふと寧ろ 小さ過ぎるそこで天平時代から藤原時代の純粋の物を採って 来て建てたけれども寸法は寧ろ大きい方にして平坪で百坪二 階造りで高さ凡そ十一間あるものを建てた（略）【同上】

林は高さを重要な問題と捉えていたようで，このこと は設計を終えて帰国した直後の発言にも表れている。

歴史館には奈良の法隆寺に大阪天王寺 (※) の長所を参配し たる模型を高さ十二間ウ之に適ふ丈に設計し(略)

(傍点筆者, ※か四天王寺のことであろう：筆者註)

【前揭「林事務官長の談話」】

この発言から, 平面の大きさは展示のために必要な面 積からではなく，建物の高さに見合うように決められた ものであったことがわかる。林は美術・工芸・建築的な 面から優れたものとなるよう設計したことを述べていた が，このような点を指していたのであろう。

仏寺建築の中から法隆寺金堂をモデルに選んだ理由で あるが, 林が内部展示と日本館のモデルとの関連を重視 していたことからすれば，陳列された古美術品に法隆寺 金堂の時代のものが含まれていなかったことは矛盾であ る。しかし, 出品する古美術品が日本の各時代から集め られることが決まっていたにせよ，その詳しい内容は， 林が日本館の設計を終えて州国する明治 32 年 7 月末の 段階でも決定していなかったことが当時の新聞からわか る ${ }^{21)}$ 。これより, 内部展示となる古美術品の内容が決定 する前に林は日本館を設計しなければならなかったこと がわかる。従って, 林は法隆寺金堂の時代そのものを表 現するために，それをモデルに選んだのではないことが 推测される。

ここで当時の法隆寺の評価を見てみると, 最古の木造 建筑というだけでなく, 明治 20 年代の初めから再建非 再建説なよ゙多くの論考が著されており, 日本美術の出発 点として美術史的に注目を浴びる建物であった淿。特に 林の建築意匠や設計についての知識との関連で注目され るのは, 伊東忠太の学位論文「法隆寺建築墖」が明治 
31 年に発表されたことである。これは主要な建築の 1/50の図や詳細図を含んでいたから，建築家ではない 林が日本館を設計するのに貴重な資料となりうるもので あって，また同年 2 月の『東京帝国大学紀要工科第一冊 第一号』に揭載されたから，比較的入手しやすい状況に あった。このように, 再建非再建論争などの成果から, 当時法隆寺ほどの豊富な資料が集まっていた建築物は他 になく、このことは林に法隆寺を選ばせた理由の一つに なったと考えられる。

また，『報告書』の記述からは，法隆寺金堂が選ばれ たのは，高さよりも歴史的古さをより重視した結果であ ることが指摘できた。林は法隆寺金堂を選んだ理由を明 らかにしてはいないが，既に述べたように，高さを重視 していた。ところが，法隆寺金堂を「日本に於ては小さ くも見へぬ」としているから，「日本建築」としては高 い部類に入るとはしながらも，代表的なものとは見なし ていないようである。逆に，高さを最も重視して法隆寺 金堂を選んだのではないがゆえに，日本館の高さに苦労 したとも解积できる。これより，法隆寺金堂をモデルに 選んだのは, 高さを最重要視した結果ではないことが確 認できる。

歴史的古さについては，林が日本館で古美術品を展示 するに際して, 西洋での日本美術の認識について述べた 興味深い発言がある。

日本を西洋で知ったと云ふものは全く其古い美術品を見て此 国は古い国である此国の文明は斯の如き度に進んで居ったも のかと云ふことを知って警いた（略）

此れ等の品物の多くは徳川家時代に出来たものである然るに 日本に永く滞在して居った人だとか又た見物に来た人が驚嘆 して話す所は何であるかと云ふとモソット古い所であって殊 に或る地方に堂塔伽藍があうて其中には二年以上のものが 伝うて居る実に其精巧驚くざく其傑作に到うては埃及齐䐳の 有名物亡甲之を相争ふて居ると云ふことを聞き及び又サウ云 ふ人達が書いた紀行文とか其他日本の歴史上に於て追々出来 てきた書物などを見ると益々真に日本の古美術と云ふものは 殆ど末だ海外の公衆に知られていないと云ふことが判った

(傍点筆者)【前揭「巴里博覧会と日本古代美術」】

日本に千年以上も昔の建築が残っており，それらの中 にはエジプト・ギリシャの建築に比肩する傑作があるこ とが知られていないとしているのである。これより，林 は, 日本美術の永い歴史が西洋では認識されていないこ とに留意していたことがわかる。

さらに，林が歴史的古さを重視していたことは，日本 館で法隆寺金堂の形態に混在させた建築や時代として挙 げたものからも確認できる。林は，天平時代から藤原時 代までのものや四天王寺の長所を用いたとしており，こ のことから花頭空や金色堂の壁面意匠以外にも混在が あったことがわかるが23\}，それらは，いずれも時代的に 古いものであり, 特に四天王寺は幾度も再建されてはい るが，法隆寺と並んで日本における仏寺建築の最も古い
形態を伝えるものであった。よって，林は日本が永い歴 史を持ち，早くから美術・建築が高度に発達していたこ とを西洋に知らせるために，歴史的古さの表現を重視し て，モデル選びを行ったと言えるであろう。

さらに，林が仏寺建築を日本館のモデルに考えた第二 の理由は，内部展示から導かれたものであった。歴史的 古さを重視したことと関連して，この時に内部の美術品 の淵源として，日本での現存最古の仏寺建築である法隆 寺金堂をモデルに選んだことは充分に考えうる。

混在の理由について林は直接に説明してはいないが, 他の発言から，内部展示と林の日本館に対する発想から もたらされたと思われる。

内部展示は, 前回のシカゴ万国博の鳳凰殿と同様に日 本の古美術品の陳列であった。鳳凰殿の各棟は展示物か ら内装にいたるまで特定の時代を再現しようとしていた から, 外観も基本的にはその時代の意匠に則っていた しかし，今回の展示物は各時代から集められた日本を代 表する古美術品であったから，『報告書』に記されてい るように，日本館は特に一時代を表現する必要は無かっ たのである。

さらに，林の日本館に対する発想は，このことをより 進めたであろう。先にも述べたように，林が日本館の形 態に仏寺建築を用いた第二の理由は，内部展示と建物を 結び付けたところから導かれたものであり，この発想に よれば，建物が展示内容を表現することになる。ところ が，過去の名建築や様式に日本館の範を求める限り，そ れを忠実に再現したならば，特定の時代を表現すること になってしまう。従って, 林は日本館のモデルをどの建 築に採ろうとも，特定の時代を表現することを避けるた めに，モデルとは異なる時代の意匠を混在させねばなら なかったのではないだろうか。

日本館が粗雑なものと評価されたことは, 設計者が素 人であるから当然とも言えるが，直接には材料と施工に 原因があった。前回の鳳凰殿では, 材料を日本で調達し て切組し，さらに現地に大工などの日本人技術者を派遺 して施工したのに対して，今回は，材料は現地で調達さ れ，施工もフランスの業者によって行われた。いわば， 代用品を用いて素人が建てた日本館であるから，避けが たい結果であったと言える。また，林は施工業者が決定 してまもなくの明治 32 年 6 月 16 日にはパリを出発し帰 国しており，施工期間の大半の現場管理がフランス人技 師だけであったことも，これに拍車をかけたと言ってよ い。

だが,そのような方法を採らねばならなかった理由は， 敷地確定が遅れたことにあった。その遠因は林が自ら日 本館を設計したことにあったが，これ以外にも「日本建 築」の形態を採る日本館建設に対する林の意識が敷地確 定の遅れを許しだと考えられる。事務官長に就任した当 
初, 古美術品の展示をフランス側が建設した建物内に計 画したことは，林に日本館建設の積極的な意思が無かっ たことを示している。また，日本館に複数の時代の意匠 を組み合わせた目的は，「日本建築」の粋を表現するこ とにはなかった。さらに，林は日本の古美術に相当の知 識がありながらも，日本の美術界においては西洋美術推 進派であり，九鬼ら伝統的日本美術の推護者達とは反対 の立場に立っていた ${ }^{25)}$ 。従って，日本館が本格的な「日 本建築」として評価されない原因の一つは，日本美術に 対する林の意識に帰してもよいであろう。

\section{V. 結 び}

日本館の建設が決定したのは,九鬼が副総裁を辞任し, 林が事務官長に就任した後であり, その設計は林が自.ら 主導したものであった。従って, その形態に九鬼の思想 が直接的には反映することは無く, 林の思想が表されて いた。しかし, 日本館は日本の古美術品を展示する施設 として建設されたものであり, その展示が計画され決定 したのは九鬼の副総裁在任時であった。フランス側がこ れらの陳列場所を準備していなかった以上, その時点で 日本館建設は当然の結果であったと言える。古美術品の 出品は, フランス側からの要請があったにせよ, 以前か ら計画されており, 九鬼の日本美術に対する誇りがそこ にはあったと考えられるから，間接的にではあるが，九 鬼の存在が日本館建設を招いたと言えよう。

日本館の設計は,レニエとプティグランだけではなく 建築家としては素人である林か関与していた。特に「日 本建築」の形態については，林が「設計者」と呼べるよ うな主導的な役割を果たしたことは間違いない。

林が設計するうえで,古建築をモデルに採ったことは, 鳳凰殿という前例を踏裝したといえるだろう ${ }^{26)}$ 。林がモ デル選定に際してまず設定したのは, 仏寺建築であるこ とであった。その理由の一つにそれが日本の建築として 誇るべきものであるとしている点は，この日本館が日本 人にとっての「日本的なもの」の表現であったことに他 ならない。

しかし，法隆寺金堂をモデルに選んだことは，対外的 な評価を期待した結果であった。それをモデルに選んだ 理由には，当時史学的に注目され資料が豊富であったこ とがあろう。より重要な理由は歴史的古さや内部展示と の関連で，前者はパリで建てられることを考虑したもの であり，林がこのことを強く意識していたことが指摘で きた。前回のシカゴ万国博の場合も今回と同様に歴史的 古さを表現することを重視していたが，その時の日本館 のモデル候補には，歴史的古さよりも「日本的なもの」 に対する積極的評価から金閣寺と鳳凰堂が挙がり，最終 的に後者が選ばれて鳳凰殿が建設された。以上のことか ら, 今回の日本館のモデル選定は鳳凰殿の場合と比較す

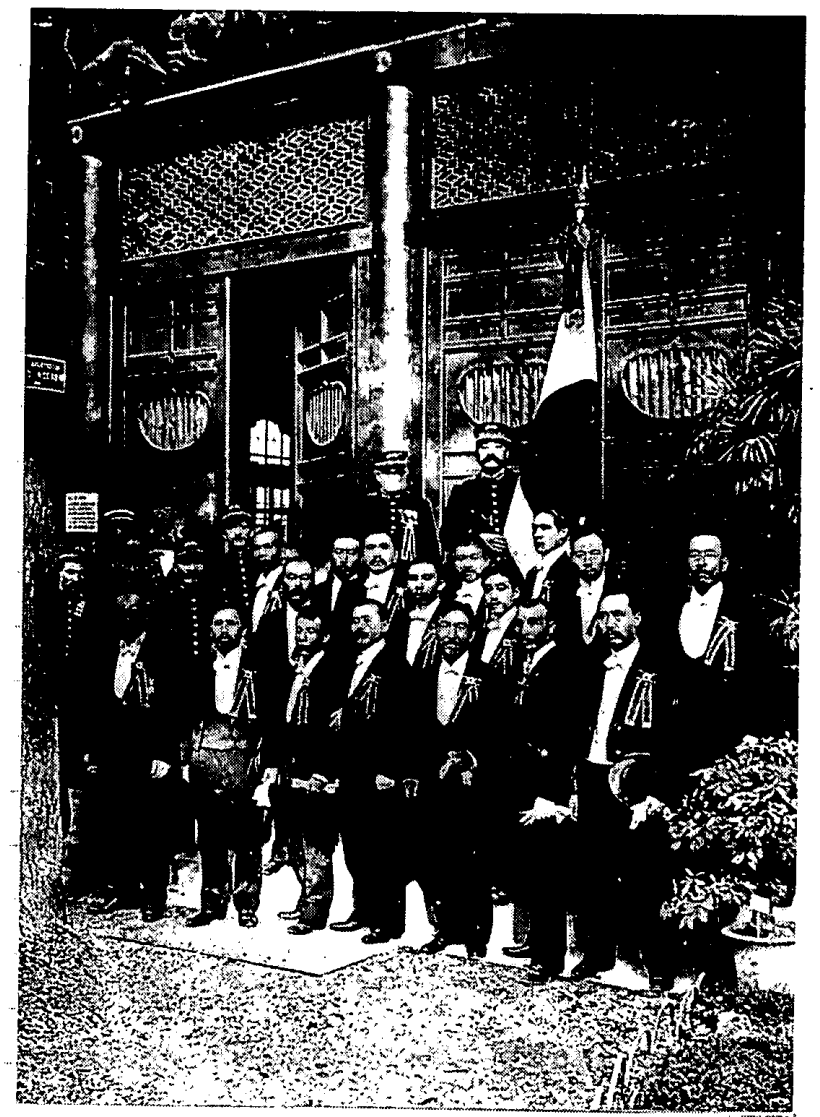

図一４日本館正面扉【「千九 $○ ○$ 年巴里万国博覧会臨時博覧会 事務局報告」(農商務省, 明治 35 年)!

れば「旧本的なもの」の積極的な評価の結果であると は言えない。

林は日本館に法隆寺と異なる時代の意匠を混在させた がそれらには，花頭空や金色堂の壁面意匠以外にも栈 唐戸があったことが現存する写真から確認される。これ は鎌倉時代以降のものであるから林が用いたとした時代 とは異なり, 混在の根拠が示されてはいない。しかし, ここにこそ「伝統継承に対する（略）日本館の設計者の

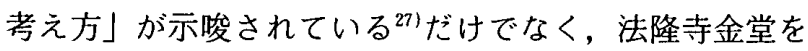
モデルに選んだのと同様の, 日本館の評価に対する林の 対外的期待が表れていたと筆者は考える。林は明治 17 年以来パリで美術商を営み, 成功を収めていたから、フ ランス人の日本美術に対する好みを把握していたに違い ない。報告書』では, 法隆寺金堂を再現した場合, 壁 面意匠が簡素過ぎるとしていたが，このことは，フラン ス人の嗜好を前提としていたはずである。従って, 混在 させた意匠は，日本館に対するフランス人の評価を高め ることを目的として選ばれたとしてよいであろう。

法隆寺金堂と時代的に異なる意匠を混在させたこと自 体は，意匠や採光などの問題以外にも，展示内容が関係 していた。今回の日本館の展示物は日本美術の変遷を示 すものであったから，特定の一時代を表現する必要はな かった。さらに林の発想からは，展示物が各時代から集 められた古美術品であるため，日本館は特定の時代を表 
現してはならなかったと思われ，そのことを避けるため にも, 複数の時代を意匠を混在させるという折衷主義的 手法が用いられたとしてよいであろう281。従って，展示 品が特定の一時代のものでなかったことが, 法隆寺金堂 をモデルに採りながらも, 複数の時代の意匠を混在させ た強い動機となったと言えよう。

このように，過去の建築様式や名建築にモデルを採り ながらも，それとは異なる時代の意匠を混在させた建築 のより早い例としては，シカゴ万国博の凰凰殿がある。 しかし，そこでの混在は，異なる時代を表現した建築物 の集合体であることに原因があった。しかし，万国博の 日本館の歴史を概観すれば，複数の棟からなる日本館は 鳳凰殿以外に無く, 殆亡゙が今回のように一棟で混在が行 われている。また，万国博の日本館以外では，管見によ れば明治 28 年の木子清敬・伊東忠太設計による平安神 宮があり，桓武天皇時代の平安京大内裏の模造を目指し たものであるが，異なる時代の意匠を混在させたもので はない299。従って, 今回の日本館はこの種の建築の最も 初期の例として重要である。

また，この日本館での混在は，内部展示と重要な関係 があった。しかし，藤岡・深谷両氏は戦前の日本館に， 内部展示と関係ある時代の様式を混在させるよりも, 複 数の時代の椂式を混在させて「日本建築」の形態を発展 させようという姿勢が見られることを指摘されてい る30!このことがこれ以降の日本館で指摘できるならば, 混在の目的が当初とは変化していったことになる。

以上のことから，この日本館は，万国博の日本館さら には近代和風建築の形態が発展してゆく上で, 複数の時 代の意匠を混在させるという手法を示した雛形として, 建築史的意義が認められねばならない。

註

1) 藤岡洋保・深谷康生「戦前に海外で開かれた国際博覧会 の日本館の和風意匠について」阳本建築学会計画系論文 報告集」(1991.1)

2）鳳凰殿については，拙稿「1893 年シカゴ万国博における 鳳凰殿の建設経緯について」「日本建築学会計画系論文報 告集」(1991.11) および「鳳凰殿の形態とその成立要因 について」「日本建築学会計画系論文報告集」(1992.4) で既に報告している。

3）「建築雑誌】（M 34.6）での記事「西半球大博覽会に於け る日本古代博覧会」中に「巴里博覧会に於ける法隆寺殿 の建物の粗なるに比すへくもあらす」と評されている。

4）本稿で用いた「混在」は, 複数の時代の建築意匠が全体 の中でそれぞれの形態を確認できるような状態で存在し ていることを指しており，「折表」や「混淆」などの類似 の概念を含む広い意味で用いていると理解して頂きたい。 なお，本稿では，これ以降は敢えて「」で括ることは 行わない。また，語句そのものは，註1）に挙げた藤岡・ 深谷両氏の論考から用いたものである。

5）「千九○○年巴里万国博筧会臨時博覽会事務局報告」(農
商務省, 明治 35 年)

6）カロリーヌ・マチュー「ジャポニスムと簡素さ」国立西 洋美術館学芸課編「ジャポニスム展 19 世紀西洋美術へ の日本の影響」(国立西洋美術館, 1988 年)。マチュ一氏

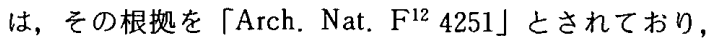
これはフランス側の報告書もしくは建築申請時の資料の 番号と思われるが，確認することはできなかった。なお， 註 1）の藤岡・深谷両氏の論考では,この建物の設計者 名を「本邦事務局」とされている。

7）調查した新聞は『読売新聞】の明治 29 年から 33 年, 『東 京日日新聞」の明治 30 年から 33 年の二紙である。

8）定塚武敏「画商林忠正」(北日本出版社, 昭和 47 年) お よび「海を渡る浮世絵一林忠正の生涯一」（美術公論社, 1981 年)

9）外報「仏蘭西・千九百年ノ万国博覧会」「官報」（M 25.7.26）および外報「仏蘭西・千九百年ノ万国博覧会開 設ノ布告」「官報」（M 25.8.27）

10）明治 29 年 12 月 26 日の「臨時博覧会事務局告示第二号」 の「明治三十三年巴里万国大博覧会出品規則」の第二条 一の条文は「美術品八各自特得ノ妙技习発揮シ本邦固有

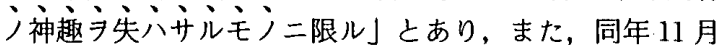
から 12 月にかけて行われた評議員会で決定された「出品 選択ノ方針」でも「美術工芸品八意匠, 精巧, 堅军タ主 トシ特二其趣味公十分本邦高趣）気格户保持シ而シテ外 人ノ用具二応用スルニ足ルヘキモノヨ撰つ事」とある。(傍 点はいずれも筆者による)

11）当時の九鬼は，剛倉覚三（天心）の校長辞任などを引き 起こした，いわゆる.「東京美術学校騒動」に関係してい たと言われており，これが副総裁辞職の理由と考えられ る。

12）註 8）に挙げた定塚氏の研究では, 曽禰以外にも伊藤博 文や西園寺公望らからの信頼が林を事務官長に引き立て たとされている。

13）日野永一「万国博覧会と日本の「美術工芸」」吉田光邦編 「万国博覧会の研究」(思文閣出版, 1986 年) より。具 体的には, 註 10）に示した「出品規則」の第二条一は明 治 31 年 5 月 5 日の「臨時博覧会告示第七号」により,「美 術作品八純正ナル美学ノ原則二基キ各自力意匠卜技能卜 ヨ発揮スヘキモノナレハ作品物八作者ノ創意製出セシモ ノ二限ル (略)」となり,「美術工芸品」と記していた第 二条二は「優等工芸品八美術き応用シ製作良好ニシテ鑑 賞実用其宜习得タルモノニ限ル」と变わった。

14）臨時博覧会事務局官制第三条には「副総裁八勅任官 $尹$ 以 テ之ニ充ツ」とある。兽雬は司法大臣を辞めた時点で勅 任官も免官となっており，このことから，副総裁として の資格も失った。

15）これの邦文原稿は, 農商務省蔵版「稿本日本帝国美術略史」 (国華社, 明治 34 年) として出版されている。

16）「巴里博覧会に付我国の申込面積」「読売新聞」(M 30.6.7) より。

17）臨時博覧会録事「仏国巴里万国博覧会本邦所要ノ陳列場 等ノ要求」官報」(M 30.7.16) より。

18）この万国博ではフランスの汽船会社メッサジュリー・マ リチーム社がパゴダなど同社の航路がある国々の建築物 を集めたパヴリオン「世界一周パノラマ館」を建設して おり，日本にも航路があったことから五重塔や山門が建 
てられた。山門は日本で切組され運ばれたものであった が、前掲のマチュー氏の論考によれば，五重塔を建てた のは建築家アレクサンドル・マルセルである。このこと からすれば，日本館の「日本建築」の形態を設計する段 階で, レニエとプティグランの外国人建築家が林と共同 できた可能性は否定できない。

19）この時, 法隆寺で金堂と同様に日本最古の建築の一つで あり,より高い五重塔が選ばれなかったのは，展示施設 として不適当との判断があったのであろう。

20)「秀衡ノ光り堂」は中尊寺金色堂を指すと考えられるが, その壁面は，黒漆塗りに金箔押しである。対して，これ に擬したとする日本館の壁面は，「報告書」の説明によれ ば,「スタッフ」(スタッコのことか)で下地を作り黒く塗っ た上に金泥を施し,梨地のように見せたとしている。また， 空上の壁面には, 天女と, その周囲に鳳凰や紗綾形を配し, 窓下の壁面にも，蓮の花や葉をあしらっている。

21）明治 32 年 8 月 14 日の「読売新聞」「よみうり抄」闌に掲 載された「巴里博覧会の本邦参考品」で, 法隆寺金堂を 模した日本館に陳列する「古代美術」が未だ決定してい ないことを報じており，これ以外にも同樣の記事は散見 される。

22）足立 康〔法隆寺再建非再建論争史】(龍吟社, 昭和 16 年) によれば，真の意味での日本芸術史は飛鳥時代から始ま るとした上で, 現存の法隆寺が飛鳥時代のものか白鳳の 再建によるものかは日本芸術史研究の一出発点となるも のであるから,この問題は明治 20 年頃より論議され始め たとしている。また, 村田次郎・近藤 豊「法隆寺建築 文献目録】（昭和 30 年, 彰国社）からは, 林忠正がパリ に出発する明治 31 年 7 月までの段階で, 法隆寺に関する 論文や著述は, 再建非再建設だけでなく総説的に述べた ものまで含めると，23 篇を数えることができる。

23）藤原時代については，日本館の壁面が中尊寺金色堂を模 したものであることから確認できるが，これ以外につい ては実際によ゙のような部分を指しているのかは, 写真な ビの現存する史料からは確認できなかった。

24）凰凰殿は，平安中期・室町時代 - 江戸時代を各々表現し た三楝の建物からなっていた。全体のモデルとは別に， その各棟も，それぞれモデルを持っていたが，それとは 異なる時代の意匠を混在させていた。しかし，その混在 は消極的なもので, 三棟全体での統一感を生み出すこと を目的としており, 複数の時代を表現した建築物の集合 体であることに起因していた。

25）特にそれが顕著にわかるのは, 明治 23 年に行われた明治 美術会第二回大会における「日本絵画の未来」と題され た外山正一の講演に対する林の反論である。これは，森 鷗外を含む三者の有名な論争であるが，ここで林はフェ ノロサらの日本画進派を強く批判しており，それが九鬼 や岡倉覚三を指していたことは間違いない。また，明治 26 年のシカゴ万国博の美術出品に関して, 洋画家たちは 当時の事務局副総裁であった九鬼の洋画を排斥しようと
する姿勢に反発して，出品を取り消し，さらに「鬼征伐」 と題した九鬼攻撃のパンフレットを作製したが，これを 金銭面を含めて背後から支援したのが林忠正であったと いわれている。ただ，林はシカゴ万国博や今回のパリ万 国博でも事務官長任命前に, 臨時博覧会事務局評議員に 任命されており，九鬼が林を万国博参同事業から排除す るようなことは無かった。さらに，林がパリ時代から様々 な形で援助していた黒田清輝に関連した事件を見ると， 状況は変化したように思える。明治 28 年の第四回内国勧 業博覧会での黒田の作品「朝然」が裸体画であることか ら問題となった時, 擁護したのは九鬼であったし, さら に同 29 年から黒田は, 九鬼と関係の深い岡倉が校長で あった東京美術学校に在職していた。このことは複雑な 問題も絡むものであるから,これ以上の論及は避けるが, いずれにせよ，今回のパリ万国博当時には，両者の関係 はかってほどの対立はなかったのではないかと考えられ るが, 美術に対する両者の基本的な姿勢までも大きな変 化があったとは思われない。

26）形態をまとめる技術的な問題からモデルを必要としたの は，先に挙げた鳳凰殿に関する拙稿で見た通りである。 また，万国博の日本館建築が前例を参照する傾向にある ことは, 井上章一氏が「日本館のエキゾチシズム」吉田 前揭「図説万国博覧会史1851-1942」の中で指摘されて いる。

27）註 1）に示した論考で, 藤岡・深谷両氏は「範となる時 代の様式や名建築との相違の部分にこそ，伝統継承に対 するこれらの日本館の設計者の考え方が示唆されている」 ことを指摘されている。

28）藤岡洋保氏は「明治大正期の日本の建築界における「日 本的なもの」」「日本建築学会大会学術講演梗概集F」(昭 和 62 年) で, 明治・大正期の「日本趣味の建築」の背景 に折衷主義があったことを指摘されている。また,藤岡・ 媣谷両氏は註 1) に挙げた論考で,「日本建築」の形態を 持つ日本館は「日本趣味の建築」の範疇に含まれるとさ れている。

29）平安神宮の形態には, 桓武天皇時代の大内裏とは異なる と考えられる意匠も見られるが，これは時代考証上の誤 りに止まると思われる。また, 平安神宮の建築について 設計者が自放著した木子清敬・伊東忠太「京都紀念殿建 築談」『建築雑誌」(M 26.12, M 27.2\&3) 加らも, 異な る時代の意匠を混在させたことは窥われない。

30）藤岡洋保氏は「大正中期から昭和戦前にかけて建設され た和風意匠の博物館について」「日本建築学会大会学術講 演梗概集F」(平成元年)で，これらの博物館は展示物之 関係のある時代の様式とは無関係に複数の時代の様式を 折哀する傾向があることを指摘されており, 註 1) の藤 岡・深谷両氏の論文で, 万国博日本館に見られる設計態 度も本質的にはこれと同じであるとされている。

(1992 年 10 月 10 日原稿受理, 1993 年 5 月 11 日採用決定) 